
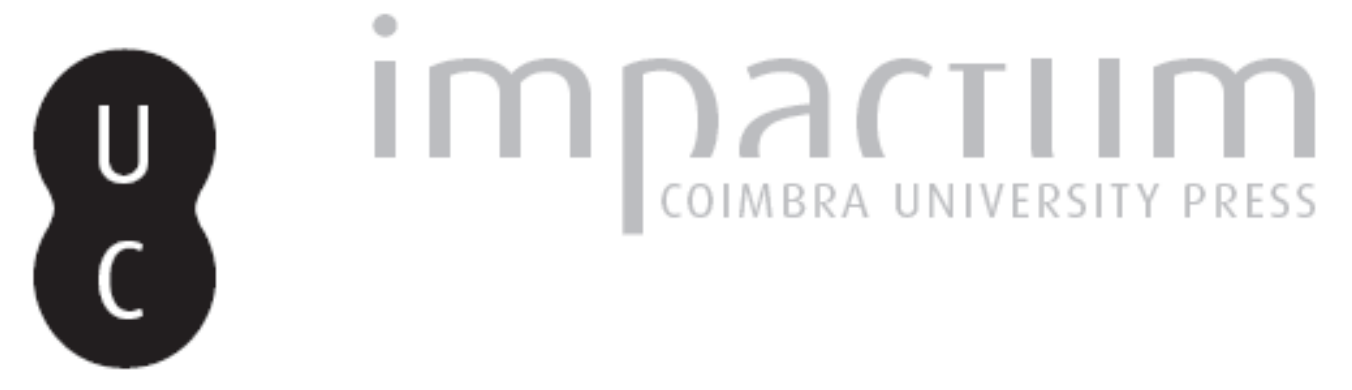

\title{
Negação e virtualização em Niklas Luhmann
}

\author{
Autor(es): Braga, Joaquim
}

Publicado por: Imprensa da Universidade de Coimbra

URL persistente:

URI:http://hdl.handle.net/10316.2/42832

DOI:

DOI:http://dx.doi.org/10.14195/0872-0851_48_9

Accessed : $\quad$ 26-Apr-2023 14:34:03

A navegação consulta e descarregamento dos títulos inseridos nas Bibliotecas Digitais UC Digitalis, UC Pombalina e UC Impactum, pressupõem a aceitação plena e sem reservas dos Termos e Condições de Uso destas Bibliotecas Digitais, disponíveis em https://digitalis.uc.pt/pt-pt/termos.

Conforme exposto nos referidos Termos e Condições de Uso, o descarregamento de títulos de acesso restrito requer uma licença válida de autorização devendo o utilizador aceder ao(s) documento(s) a partir de um endereço de IP da instituição detentora da supramencionada licença.

Ao utilizador é apenas permitido o descarregamento para uso pessoal, pelo que o emprego do(s) título(s) descarregado(s) para outro fim, designadamente comercial, carece de autorização do respetivo autor ou editor da obra.

Na medida em que todas as obras da UC Digitalis se encontram protegidas pelo Código do Direito de Autor e Direitos Conexos e demais legislação aplicável, toda a cópia, parcial ou total, deste documento, nos casos em que é legalmente admitida, deverá conter ou fazer-se acompanhar por este aviso.

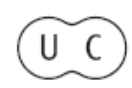




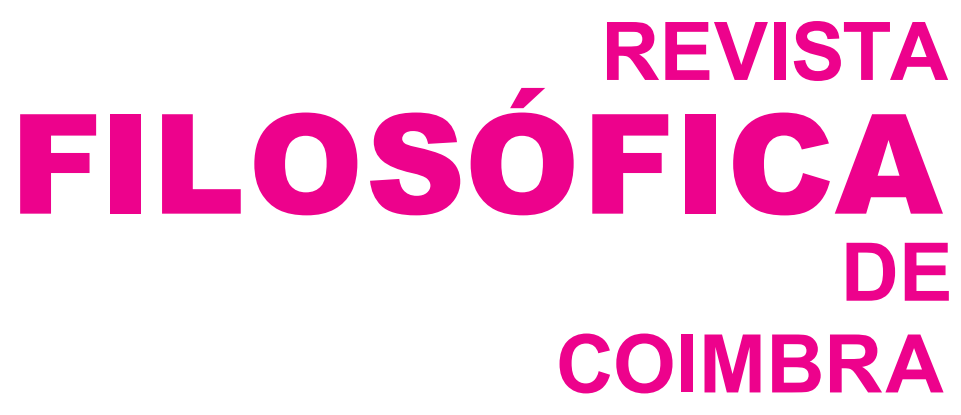

vol. 24 - número 48 - outubro 2015

vol. 24 - número 48 - outubro 2015

Fundação Eng. António de Almeida

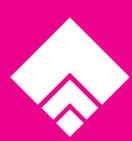




\title{
NEGAÇÃO E VIRTUALIZAÇÃO EM NIKLAS LUHMANN
}

\author{
JOAQUIM BRAGA ${ }^{*}$
}

Resumo: Com este texto pretende-se articular dois conceitos que fazem parte da reflexão de Niklas Luhmann sobre os processos de formação de sentido. Trata-se dos conceitos de "negação" e "virtualização", que, na teoria dos sistemas luhmanniana, contribuem, de forma decisiva, para a caracterização das operações dos sistemas psíquicos e dos sistemas sociais. Tendo em vista a compreensão do desempenho operatório das possibilidades de sentido inactualizadas no interior dos dois sistemas, um dos objectivos principais desta reflexão passa pela especificação conceptual da negação, bem como pela ampliação teórica do espectro das suas funções.

Palavras-chave: actualização, negação, selecção, sentido, virtualização.

Abstract: With this paper we intend to articulate two concepts that are part of Niklas Luhmann's reflection on the processes of meaning formation. These are the concepts of "negation" and "virtualization," which, in the Luhmannian systems theory, decisively contribute to the characterization of the operations of psychic and social systems. With a view to understanding the operative performance of the unactualized meaning possibilities within the two systems, one of the core objectives of this reflection involves the conceptual specification of negation, as well as the theoretical broadening of the spectrum of its functions.

Keywords: actualization, meaning, negation, selection, virtualization.

\section{Introdução}

À primeira vista, a coexistência teórica dos conceitos de "virtualização" e "negação" poderia, por si só, indicar o pressuposto, tantas vezes dissemi-

* Bolseiro da Fundação para a Ciência e a Tecnologia, Faculdade de Letras da Universidade de Coimbra, Unidade I\&D LIF - Linguagem, Interpretação, Filosofia; email: joaquim.braga@yahoo.com. 
nado, de que o segundo é o efeito imediato do primeiro. Porém, a existência deste pressuposto assenta, em larga medida, na marginalização digital a que foi votada a virtualidade, nomeadamente através das construções semânticas apoiadas no binómio ontológico real-virtual e cuja articulação programática redundou na máxima "o virtual é a negação do real". Apesar da imensa popularidade que atingiu, a crítica desta máxima não se encontra apenas nas inferências teóricas que Gilles Deleuze faz da filosofia bergsoniana. Como se depreenderá posteriormente, a relação sistémica entre negação e virtualização presente no pensamento luhmanniano sustenta, de forma positiva - porque estrutural -, as bases cognitivas e comunicativas da construção do real, e é dela que, em larga medida, também dimanam alguns dos critérios teóricos fundamentais que dão corpo à análise da sociedade moderna proposta pelo autor.

$\mathrm{Na}$ acepção luhmanniana, é possível encontrar uma negatividade do virtual, que, não sendo representativa dos pretensos efeitos ontológicos transportados pela máxima acima indicada, se revela como traço genésico das dimensões que determinam o próprio conceito de virtual. A especificidade deste último e do traço referido só podem ser aclarados quando situados no interior da questão do sentido - a magna questio que trespassa toda a teoria dos sistemas luhmanniana. É precisamente nesta questão que reside a rede conceptual fundadora e unificadora dos conceitos de negação e virtualidade, visto que o sentido gera o super-médium inter-sistémico através do qual consciência e comunicação se individuam, interpenetram e autonomizam. $\mathrm{O}$ «primado funcional da negatividade» ${ }^{1}$ nos processos de formação de sentido, tal como é descrito por Niklas Luhmann, permite-nos encontrar nele um dos pontos vitais para a compreensão da virtualidade e das suas múltiplas formas de manifestação.

Estando o pensamento de Luhmann comprometido com a elaboração e sistematização de uma teoria da sociedade - mormente as bases que permitem descrever a sociedade moderna como funcionalmente diferenciada -, a objectivação do primado da negação atinge a sua maior e melhor expressão nos processos comunicacionais inerentes às operações dos sistemas sociais. Embora o autor também aplique as estruturas do sentido às operações dos sistemas psíquicos, dando continuidade, nesse aspecto, à herança fenomenológica, é a ampliação teórica do sentido ao domínio dos sistemas sociais que nos revela, de forma cabal, os efeitos da negatividade do virtual nos processos de diferenciação da sociedade. Deste modo, a relação "negação-virtualização" tem já implícita a marca da diferenciação sistémica da socie-

1 Niklas Luhmann, "Sinn als Grundbegriff der Soziologie”, In: Habermas, J./Luhmann, N., Theorie der Gesellschaft oder Sozialtechnologie - Was leistet die Systemforschung? (Frankfurt am Main: Suhrkamp Verlag, 10. Aufl., 1990), 25-100, 35. 
dade, marca essa que nos obriga a acentuar tanto o prisma social da formação de sentido quanto as implicações funcionais que dele dimanam para a observação da evolução dos próprios processos de formação.

\section{Sistema e sentido}

Aceitando as premissas fundamentais da epistemologia construtivista e rejeitando a polarização sujeito-objecto incutida pela epistemologia cartesiana, Luhmann participa do pensamento filosófico moderno que intenta proceder à substituição da Seinsfrage (Was?), que percorre toda a metafísica clássica, pela Sinnfrage (Wie?). O “como?”, na sua expressão luhmanniana, gera o seu ponto de interrogação no interior das operações dos sistemas; e, na teoria dos sistemas luhmanniana, há dois sistemas que operam mediante a formação de sentido: sistemas psíquicos e sistemas sociais. O sentido é sempre um produto - e não uma qualidade, uma substância - das operações inerentes aos sistemas que dele fazem depender os seus registos autopoiéticos. Neste aspecto, a mesma ideia pode ser formulada a partir de Gilles Deleuze, nomeadamente quando, em Logique du sens, o filósofo afirma que «le sens n'est jamais principe ou origine, il est produit. $\rangle^{2}$ Abandonada a ideia de que o sentido é somente uma categoria da consciência ou o puro resultado das formas de interacção linguísticas, é, pelo contrário, graças ao facto de os sistemas socias e os sistemas psíquicos serem Sinnsysteme que os seus acoplamentos operatórios são exequíveis ${ }^{3}$. Ao contrário das pretensões de Jürgen Habermas, que apresenta a intersubjectividade mediada linguisticamente como o verdadeiro curso identitário do sentido, argumenta Luhmann que, dada a sua natureza pré-linguística, o sentido põe em jogo processos perceptivos - como, por exemplo, a minha percepção da percepção do outro - que não são redutíveis aos processos estritamente suportados pela linguagem.

Segundo Luhmann, o sentido é um produto das operações sistémicas que têm uma funcionalidade recursiva, sejam estas dirigidas ao passado (kontingente Operationen) ou, noutra dimensão temporal, às «possibilidades de observação» (Beobactungsmöglichkeiten) futuras ${ }^{4}$. É dando consequência teórica a esta ideia que podemos compreender a concepção do «mundo como realidade virtual» (die Welt als virtuelle Realität) ${ }^{5}$. Trata-se, em rigor, de uma

2 Gilles Deleuze, Logique du sens (Paris: Les Éditions de Minuit,1969), 90.

3 Niklas Luhmann, Die Wissenschaft der Gesellschaft (Frankfurt am Main: Suhrkamp Verlag, 2. Aufl., 1994), 620.

4 Niklas Luhmann, Die Gesellschaft der Gesellschaft, Band I (Frankfurt am Main: Suhrkamp Verlag,1997), 47.

5 Ibidem. 
tese fundacional do construtivismo operatório luhmanniano, que intenta colocar o conhecimento sob a égide dos possíveis - quer em relação à construção da realidade quer em relação à observação da construção que por outros sistemas é feita. Só atendendo ao uso disseminado da expressão "realidade virtual" é que nos levará a encontrar nesta concepção o pressuposto ontológico de dois mundos contíguos, ainda que mutuamente excludentes. Mas tal não é, aqui, o caso. A distinção comummente efectuada entre "mundo real" e "mundo virtual" não é seguida por Luhmann, pois uma concepção de mundo, longe de poder ser pensada a partir de uma entificação ontológica do que é (e não é) real, ${ }^{6}$ remete-nos sempre para o sentido que acompanha as operações autopoiéticas e auto-referenciais de um determinado sistema (psíquico ou social, neste caso). São as operações mediadas pelo sentido que constituem o real, não havendo, consequentemente, um real que precede ou transcende as mesmas operações. O mundo, na acepção luhmanniana, é, então, um mundo-na-diferença; o que pressupõe também dizer: fora ${ }^{7}$ do sistema não há um mundo coisificado (Welt), mas antes um meio-ambiente (Umwelt), mais precisamente o meio concernente a esse sistema específico. Logo, da distinção que o sistema opera entre sistema e meio resulta o conceito de mundo, que indica a unidade dessa diferença. A unidade, por sua vez, não pode ser observada, já que, nela, se encontram simultaneamente incluídos observador e observado. A ideia de mundo comporta, assim, uma natureza paradoxal.

$\mathrm{Na}$ análise que faz da teoria dos sistemas abertos, Luhmann revela-nos que uma das debilidades encontradas diz respeito à relação entre sistema e meio-ambiente, que, enquanto tal, permanece teoricamente indeterminada. Desta relação não advém qualquer indicação substancial sobre a diferença entre sistema e meio-ambiente, nem tão-pouco sobre o facto de, neste último, estarem já incluídos outros sistemas - o que, como facilmente se depreende, deve sempre conduzir a uma (segunda) diferença entre sistema e sistemas ${ }^{8}$. É através desta segunda diferença que se torna possível formular questões relativas aos condicionalismos que se geram entre sistemas distintos, como, por exemplo, entre sistema económico e sistema político. Acentue-se aqui o princípio conceptual de que, na terminologia luhmanniana, "condicionar"

${ }^{6}$ Sobre o carácter epistemológico das operações sistémicas e as principais dimensões que o distinguem da universitas rerum das teorias do conhecimento tradicionais, vide Peter Fuchs, "Die Theorie der Systemtheorie - erkenntnistheoretisch", in: Idem, Theorie als Lehrgedicht. Systemtheoretische Essays I, Hrsg. von Marie-Christin Fuchs (Bielefeld: Transcript Verlag, 2004), 181-193.

7 O advérbio não deve sugerir aqui - como se pode concluir do pensamento que a totalidade da frase encerra - uma existência independente das operações do sistema.

8 Niklas Luhmann, Einführung in die Systemtheorie, Hrsg. von Dirk Baecker (Heidelberg: Carl-Auer Verlag, 6. Aufl., 2011), 45-46. 
não é sinónimo de "determinar". Cada sistema dispõe de uma capacidade de ressonância que the permite absorver as irritações provocadas pelo seu meio-ambiente; e é, também, graças a tal capacidade que o acoplamento estrutural entre comunicação e consciência pode ser executado. É claro que, na acepção luhmanniana, a objectivação das diferenças entre System e Umwelt relativa aos sistemas psíquicos e sociais é estabelecida pelas operações apoiadas no sentido. Como nos diz o autor, «é através da mediação do sentido que a diferença entre sistema e meio-ambiente constitui o próprio sistema $»^{9}$. Aqui, a repetição do termo "sistema" na definição do próprio conceito de sistema não obedece, porém, a uma mera redundância discursiva. Luhmann deve a George Spencer-Brown tal formulação, pois o conceito de "distinção" introduzido por este último no seu Laws of Form expressa claramente a ideia de fronteira. É recorrendo à distinção entre marked state e unmarked state ${ }^{10}$, elaborada por Spencer-Brown, que Luhmann reforça a linha divisória entre sistema e meio-ambiente. Por outro lado - e é, neste ponto, que plenamente se justifica a repetição do termo -, as operações de distinção são sempre acompanhadas pela re-entrada (re-entry) da distinção naquilo que é distinguido; é, portanto, devido a essa operação que o sistema pode reincorporar a diferença entre sistema e meio-ambiente (distinção exógena) e, dada a sua natureza autopoiética, produzir a própria distinção estrutural (distinção endógena) - seja através da consciência ou através da comunicação.

Esta dupla forma da distinção está ancorada nos conceitos de "auto-referência" (Selbstreferenz) e hétero-referência (Fremdreferenz). Nas palavras de Luhmann, "o sentido tanto se refere a si mesmo como a algo fora de si.» ${ }^{11} \mathrm{~A}$ interpretação desta acepção mostra-nos que a dupla referencialidade é sempre trespassada pelo binómio "actual-potencial", deixando-se o sentido igualmente definir como «a unidade da diferença entre actualidade e potencialidade». ${ }^{12}$ Daqui também se infere que o estatuto ontológico do real só pode ser adquirido através da diferença entre actual e potencial. E, por outro lado, o sentido - que nos dá essa diferença - apenas se realiza na sua actualização. O tradicional valor ontológico dos possíveis - o "não-ser" - é, inevitavelmente, posto de parte. Logo, o sentido pressupõe sempre operações apoiadas no sentido, isto é, como reitera o autor, ele é «um produto de operações que utilizam sentido» ${ }^{13}$, e não deve, por isso, o seu modus

9 Niklas Luhmann, Ideenevolution. Beiträge zur Wissenssoziologie, Hrsg. von André Kieserling (Frankfurt am Main: Suhrkamp Verlag, 2008), 29.

10 George Spencer-Brown, Laws of Form (Leipzig, Bohmeier Verlag, $5^{\text {th }}$ Edition, 2011), 3-4.

11 Luhmann, Ideenevolution, 12.

12 Niklas Luhmann, Aufsätze und Reden (Stuttgart: Reclam, 2007), 234.

13 Luhmann, Die Gesellschaft der Gesellschaft, 44. 
operandi a uma entidade objectiva originária ou a qualquer fenómeno provindo de representações mentais. Assim, o sistema, ao mesmo tempo que faz depender as suas operações da formação do sentido, vai, simultaneamente, gerando traços mnésicos das mesmas no seu interior. Tal como Humberto Maturana e Francisco Varela haviam aplicado os mecanismos de reprodução da autopoiesis aos sistemas biológicos, também Luhmann concebe os modos de operação do sentido dentro de uma continuidade circular, capaz de assegurar, a cada momento, a reprodução das suas condições de possibilidade.

Se há, portanto, proposição (anti-mística) que desta intermutabilidade operatória entre sistema e sentido possa ser inferida, ela só pode ser a seguinte: «Podemos imaginar um mundo em que nenhum sentido é produzido e reproduzido operativamente, mas só podemos tecer propriamente esta ideia apenas através do sentido.» ${ }^{14}$

A distinção entre actual e potencial, que resulta de cada vivência (psíquica ou comunicativa) mediada pelo sentido, pode ser fundamentada pelo «excedente de possibilidades» (Überfülle des Möglichen ${ }^{15}$ ) gerado em cada processo de actualização. Os conceitos de "contingência" e "complexidade" são, para Luhmann, os correlatos teóricos que assinalam a densidade provocada pelas possibilidades em excesso abertas pela determinação significativa das vivências. Ao conceito de complexidade deve ser atribuída a categorização do "excedente" dos possíveis e a sua não integração nas possibilidades que são actualizadas. A categorização da indeterminação relativa às possibilidades não-actualizadas é, por sua vez, circunspecta ao conceito de contingência, que introduz, em todas as operações de distinção, extensões de risco e incerteza ${ }^{16}$. Das possibilidades em excesso redunda, consequentemente, uma «pressão selectiva» (Selektionszwang ${ }^{17}$ ) que obriga cada sistema a operar de forma a reduzir a complexidade fornecida pelo seu meio-ambiente. Dentro do espectro dos sistemas sociais, a arte é o melhor foco de observação das dinâmicas traçadas pela contingência e pela complexidade. Um dos desempenhos do sistema artístico reside no facto sui generis de permitir a observação «do mundo no mundo», uma vez que ele nos remete, implícita e explicitamente, para a natureza contingente que trespassa os modos de actualização dos possíveis. Logo, é também através de tal desempenho que

14 Luhmann, Einführung, 224. Uma tentativa pretensamente "existencialista" de inverter o alcance teórico desta proposição pode ser encontrada em Alois Hahn, "Sinn und Sinnlosigkeit", in: Sinn, Kommunikation und soziale Differenzierung. Beiträge zu Luhmanns Theorie sozialer Systeme, Hrsg. von Hans Haferkamp und Michael Schmid (Frankfurt am Main: Suhrkamp Verlag, 1987),155-164.

15 Luhmann, Sinn als Grundbegriff, 32.

16 Ibidem, 32-33.

17 Ibidem, 33. 
o mundo da arte nos mostra que «nenhuma realidade pode excluir a possibilidade de devir diferente» ${ }^{18}$.

\section{Sentido e observação}

Esta última asserção luhmanniana, assaz exemplificativa da possibilidade de os sistemas gerarem pontos de observação sobre as dinâmicas das suas operações, bem como de fazerem destas temas de comunicação, reforça o protagonismo teórico exercido pelos sistemas sociais na objectivação dos processos de formação do sentido. A clausura autopoiética de cada sistema não suprime a sua abertura cognitiva - pelo contrário, pressupõe-na. E, como nos é dado observar pela arte, os temas de comunicação dos sistemas sociais são, muitas vezes, sugestivos da natureza operatória dos sistemas psíquicos.

A sugestividade inter-sistémica possui, porém, uma justificação temporal. Do ponto de vista evolutivo, os sistemas psíquicos e sociais contêm uma morfologia temporal paralela, não havendo, por isso, qualquer precedência ontológica de um sujeito monádico, encerrado na sua consciência, face à esfera sistémica do social. Uma versão antropocêntrica da evolução sistémica, baseada na ideia de que o sentido contém um portador singular e identificável, não só colocaria em causa o registo co-evolutivo dos dois sistemas, como também o facto de o registo autopoiético de ambos ser diferenciado através do próprio sentido. Para o autor de Soziale Systeme, o sentido é, acima de tudo, o legítimo "portador de si mesmo, na medida em que é capaz de garantir, de forma auto-referencial, a sua própria reprodução» ${ }^{19}$. As inúmeras configurações que esta reprodução assume, assim conclui o autor, contribuem para a autonomia e diferenciação das estruturas sociais e psíquicas ${ }^{20}$. A linguagem é o mecanismo decisivo para a existência de um acoplamento estrutural entre sistemas psíquicos e sistemas sociais. Mas, e respeitando a autonomia operatória que o conceito de "acoplamento" pressupõe, tal mecanismo é ainda mais influente por não colocar em causa o registo autopoiético de cada sistema envolvido, as operações suportadas pelo sentido que, embora distintas, articulam as esferas da comunicação e da consciência. Daqui também redunda a ideia de que, ao contrário das pretensões da linguística, a linguagem não pode ser considerada um sistema - não há operações propriamente linguísticas, mas antes operações suportadas pela comunicação

18 Niklas Luhmann, Schriften zu Kunst und Literatur, Hrsg. von Niels Werber (Frankfurt am Main: Suhrkamp Verlag, 2008), 287.

19 Niklas Luhmann, Soziale Systeme. Grundriß einer allgemeinen Theorie (Frankfurt am Main: Suhrkamp Verlag, 1984), 141.

20 Ibidem. 
e pela consciência. Interpretada a partir de uma aproximação funcional, a linguagem pode ser concebida como um dispositivo que acentua e reforça a constituição selectiva dos processos comunicacionais, da mesma maneira que estes últimos podem ser entendidos como potenciadores da selectividade dos processos perceptivos.

Interpretada amplamente e, portanto, conjugada com a mediação extra-linguística, a comunicação é, para os sistemas sociais, o médium que transporta quer o problema quer a solução colocados pelo fenómeno da "dupla contingência". Porque a solução nunca encerra a determinação absoluta do problema, podemos, com Dirk Baecker, designar a comunicação como uma «Intelligenz des Nichtwissens» ${ }^{21}$, como uma forma de operar sobreposta sobre as assimetrias existentes entre sistemas psíquicos. (Formulada a partir destes últimos, é, precisamente, na comunicação que a incomunicabilidade individual de cada esfera psíquica se torna verdadeiramente perceptível). Daí que Luhmann utilize o conceito de "pessoa" para categorizar a redução sistémica que a dupla contingência fomenta. O mesmo é dizer, "pessoa" é a forma social dos intercâmbios entre ego e alter, resultante das suas múltiplas selecções efectuadas sob o regime de sentido próprio das operações comunicativas.

É na reflexividade ditada pelas operações dos sistemas sociais que a observação dos processos de formação de sentido ganha um maior grau de inteligibilidade. Do contraste entre sistemas psíquicos, veiculado e utilizado pela comunicação e cujo resultado se inscreve na diferença entre sistema e meio-ambiente, redunda o fenómeno que, habitualmente, se designa de "compreensão". Graças a este nível de observação torna-se exequível passar da formação do sentido para o da sua inteligibilidade, já que, como adverte Luhmann, o Sinnerfassen não contempla, ab initio, o fenómeno da compreensão ${ }^{22}$. Dentro da esfera social, a vivência das vivências de outro sistema, que não o meu, permite-me usufruir da condição de observador; e é através dessa nova condição que, tal como é formulada pela second-order cybernetics, não implicando uma adequação mimética entre o facto observado e as representações elaboradas pelo observador, a compreensão se reproduz como mecanismo auto-referencial do sentido.

A constituição diferencial da observação deixa-se explicar através do cálculo da forma proposto por Spencer-Brown. A primeira operação do cálculo compreende o assinalar de uma marca no espaço ainda não diferenciado. Tratando-se de uma operação estritamente de primeira ordem, ao observador apenas lhe está reservada a "entrada" da marca no espaço. Será numa subsequente operação do cálculo - denominada esta de segunda ordem - que

21 Dirk Baecker, Wozu Systeme? (Berlin: Kadmos Verlag, 2002), 13.

22 Luhmann, Soziale Systeme, 110. 
se torna possível observar a forma da distinção, ou seja, a sua "re-entrada" na diferença introduzida entre espaço marcado e espaço não-marcado. Assim concebido - através das duas operações capitais -, o cálculo conduz o observador a uma reflexividade paradoxal, uma vez que todas as determinações impostas no espaço da distinção são agora interpretadas como diferenças. Devido ao universo paradoxal que o cálculo da forma gizado por Spencer-Brown deixa antever, torna-se imperioso, como salienta Luhmann, proceder à sua descontextualização da esfera da lógica clássica, entendida esta ainda segundo os índices veritativos que a governam ${ }^{23}$.

Nesta constituição da observação - que pode ser entendida como um processo que transmuta a diferença em distinção, através do qual, como realça Peter Fuchs ao longo da suas teses sobre o fenómeno da observação, se realiza a "encenação", a "dramaturgia" de uma unidade, ${ }^{24}$ - encontra-se já presente o cunho estrutural do sentido. O facto de as operações de observação estarem dependentes de distinções justifica-se, em grande parte, pela constituição do próprio médium sentido estar ancorada no par dicotómico "actual-potencial".

O conceito de observação - nomeadamente, a observação de segunda ordem - encerra, segundo Luhmann, o pressuposto de um «Realitätsverlust» 25 , um enfraquecimento da construção imediata do real, uma vez que a ocupação directa com o mundo passa a ser substituída pela forma como o mundo é observado. A forma da observação impõe-se à dupla referencialidade do sistema (auto-referencialidade e hétero-referencialidade), inscrevendo nesta uma maior arbitrariedade nos processos de construção do real. A arbitrariedade decorre, sobretudo, do incremento da complexidade. Na observação de segunda ordem encontram-se sempre presentes dois caminhos distintos traçados pela complexidade. Por um lado, a substituição do observador pela forma da observação tende a contribuir para a redução da complexidade. Por outro, porém, o sistema vê-se obrigado a operar paralelamente com duas distinções irredutíveis, mais precisamente, a distinção (de primeira ordem) entre o observador referenciado pelo sistema e os outros excluídos, e, por fim, as distinções fornecidas pelo próprio observador observado. É, precisa-

23 Niklas Luhmann, “The Paradox of Form”, in: Problems of Form, Edited by Dirk Baecker, Transl. by Michael Irmscher with Leah Edwards (Stanford: Stanford University Press, 1999), 15-26, 25.

24 Peter Fuchs, Der Sinn der Beobachtung. Begriffliche Untersuchungen (Weilerswist: Velbrück Wissenschaft, 2004), 7-19; Die Erreichbarkeit der Gesellschaft (Frankfurt am Main: Suhrkamp Verlag, 1992), 239; Die Metapher des Systems: Studien zu der allgemein leitenden Frage, wie sich der Tänzer vom Tanz unterscheiden lasse (Weilerswist: Velbrück Wissenschaft, 2001), 139.

25 Luhmann, Einführung, 136. 
mente, aqui, que predomina o incremento da complexidade, pois tudo o que é apreendido pelo sistema está, cada vez mais, sujeito ao cunho da «contingência», do «relativo», do «artificial» ${ }^{26}$.

Para Luhmann, a Modernidade, ao desenvolver o interesse pela observação de segunda ordem - interesse este que pode ser categorizado como uma tentativa de «ver o que os outros não vêem» ${ }^{27}$, já que as distinções elaboradas pelo observador observado trazem à expressão aquilo que ele não observa, bem como os elementos excluídos nos processos selectivos -, influencia, de forma decisiva, o registo autopoiético dos sistemas apoiados na formação de sentido. Um dos exemplos mais ilustrativos desta tendência pode ser encontrado na esfera do sistema político, cuja evolução acusou a forma de como os agentes são vistos a observar, levando, consequentemente, o sistema a adoptar estratégias de antecipação das reacções dos observadores de segunda ordem.

\section{Selecção e negação}

Para demonstrar a aprioridade do conceito de "sentido", Luhmann estabelece uma distinção lapidar entre estruturas referenciais e estruturas sígnicas. As primeiras constituem o núcleo operatório do sentido e, consequentemente, não podem ser extraídas a posteriori da função do signo. Pelo contrário. Este último deve a sua função às estruturas basilares do sentido, à assimetrização entre auto-referência e hétero-referência, que, por sua vez, se inclui nas estruturas sígnicas sob a forma dicotómica do par "significante-significado" 28 . É óbvio que a assimetrização reproduzida no e pelo signo tende a contribuir, de modo decisivo, para a organização e preservação das estruturas do sentido elementares, para a diferenciação por estas introduzidas.

Da distinção entre as duas estruturas redunda um parâmetro teórico fundamental para a introdução e compreensão do fenómeno da negação no seio da teoria dos sistemas luhmanniana.

Tal como sucede com a questão do sentido, um dos maiores obstáculos a uma teoria da negação é a sua redução aos fenómenos linguísticos. Dizer que $x$ não contém $y$-por exemplo, a "rosa não é vermelha" - é uma possibilidade estrutural que a linguagem nos reserva, mas, analisada e avaliada somente através dos seus efeitos proposicionais, pode conduzir à falácia veritativa de que, como adverte John Langshaw Austin, a negação seja apenas uma

\footnotetext{
${ }^{26}$ Luhmann, Einführung, 151.

27 Luhmann, Einführung, 154.

28 Luhmann, Soziale Systeme, 107.
} 
«second order affirmation» ${ }^{29}$, isto é, e considerando o nosso exemplo, a afirmação "a rosa não é vermelha" seria, nesta perspectiva, perfeitamente substituível pela afirmação "não é verdade que a rosa é vermelha". No entanto, o reconhecimento da co-existência funcional de afirmação e negação no seio das realizações linguísticas mostra-se insuficiente para desvendar as múltiplas implicações da negação nos processos de formação de sentido - porque se trata, acima de tudo, apenas do reconhecimento lógico das manifestações expressivas da negação.

No que a este último ponto diz respeito, convém, aqui, salientar os importantes contributos dados por Gottlob Frege e Sigmund Freud. Frege não interpreta a negação como uma forma de juízo singular e autónoma. Uma vez que a natureza do juízo é sempre a da afirmação, a negação deve ser concebida como parte integrante do que é objectivado pela primeira. A este respeito diz-nos Frege que não há nenhum fundamento lógico capaz de identificar a natureza de um «pensamento negativo» ${ }^{30}$. Em qualquer asserção pode ocorrer negação, sem que esse facto conduza inevitavelmente à identificação de um juízo puramente negativo. Um dos méritos da reflexão fregeana - que será, posteriormente, abandonado por Alfred Jules Ayer ${ }^{31}$ reside na ideia de que as expressões de negação presentes num acto de fala são desprovidas do carácter ontológico tipificado pelo binómio "verdadeiro-falso". A negação, não sendo uma forma de juízo, dá-se fora da esfera psíquica do portador do juízo - ela é constitutiva do pensamento e, por isso, não se encontra sujeita a nenhum conteúdo psicológico específico da consciência. Ainda que com um alcance teórico diferente, a reflexão de Freud, tal como a de Frege, tem na sua base a descentralização da negação da esfera estritamente linguística. No seu artigo Die Verneinung, Freud introduz a negação como tendo a função de expressar os conteúdos recalcados do inconsciente. Aquilo que, num acto de fala, é negado comporta, simultaneamente, a sua afirmação, a tomada de consciência do fenómeno reprimido. $« \mathrm{O}$ reconhecimento do inconsciente pela parte do eu expressa-se através de uma fórmula negativa ${ }^{32}$. Um dos traços evidentes da fórmula negativa, tal como pode ser inferido da análise freudiana, deixa-se enunciar sob a forma

29 John Langshaw Austin, "Truth", in: Philosophical Papers (Oxford: Clarendon Press, 1961), 85-101, 96.

30 Gottlob Frege, "Negation", in: Translations from the philosophical writings of Gottlob Frege, Edited by Peter Geach and Max Black, Transl. by P. Geach (Oxford: Basil Backwell, Second Edition, 1960), 117-135, 125.

31 Alfred Jules Ayer, "Negation", in: The Journal of Philosophy, Vol. 49, No 26 (Dec. 18, 1952), 797-815.

32 Sigmund Freud, "Die Verneinung", in: Zeitschrift für Anwendung der Psychoanalyse auf die Geisteswissenschaften, XI. Band, Heft 3 (1925), 217-221, 221. 
da asserção «Isto é algo que eu gostaria de reprimir» ${ }^{33}$. Do ponto de vista psicanalítico, a negação passa a ser concebida como uma forma de dizer um não para sugerir um sim. Há, aqui, uma clara separação introduzida por Freud entre o domínio discursivo da enunciação e o domínio lógico da proposição, visto que o valor veritativo proposicional nunca suprime o valor simbólico verbalizado pelo eu. É, precisamente, na diferença entre expressão e proposição que se abre espaço para a natureza sugestiva da negação.

Estas questões, porém, ganham outra amplitude teórica quando atribuímos à negação uma função diferenciadora na discriminação de possibilidades de sentido.

Luhmann vai encontrar na teoria da informação uma primeira aproximação à relação sistémica entre negação e selecção. Tal como é fundada por Ralph Hartley, a constituição sintáctica da informação pressupõe mecanismos de negação nos processos de selecção. No entanto, trata-se, em rigor, de uma função excludente da negação, que não engloba a consideração positiva das possibilidades negadas, pois estas são, no entender de Hartley, simplesmente "eliminadas". Num contexto de comunicação verbal, assim explica Hartley, o aparelho vocal serve, muitas vezes, para transportar e transmitir ao receptor todas as selecções efectuadas pelo emissor da mensagem. O sucesso da emissão está dependente da "atenção" que consegue despertar no receptor. À medida que esta se torna permanente, o número de sequências discriminadas e eliminadas tende a aumentar, contribuindo, consequentemente, para uma maior precisão da informação ${ }^{34}$.

Vejamos as consequências teóricas que desta concepção resultaram para o desenvolvimento da teoria da informação. Hartley não menciona a questão do "sentido"; remete-nos somente para a coerência sintáctica que pode ser gerada entre sequências de símbolos seleccionados. Embora não amplamente teorizada, a questão do sentido é mencionada nas concepções de Claude Shannon e Warren Weaver. Como bem salienta Weaver a este respeito, a teoria matemática da comunicação desenvolvida por Shannon não contempla os aspectos semânticos da informação. Apenas os aspectos técnicos do processamento da comunicação são tidos em consideração, especialmente aqueles que englobam as dimensões físicas da transmissão de sinais entre emissores e receptores ${ }^{35}$, sendo, por isso, estes últimos remetidos a um mero

33 Freud, "Die Verneinung", 218.

34 Ralph Hartley, "Transmission of information”, in: Bell System Technical Journal, Volume 7, Number 3 (July 1928), 535-563, 536.

35 Warren Weaver, "Recent contributions to the mathematical theory of communication", in: Claude E. Shannon and Warren Weaver, The mathematical theory of communication (Urbana and Chicago: University of Illinois Press, 1998), 1-28, 6. 
papel passivo nos processos comunicacionais. É dessa forma que, atendendo à concepção de Shannon, se pode compreender a seguinte asserção de Weaver: «information must not be confused with meaning ${ }^{36}$. Esta asserção baseia-se no pensamento inaugural introduzido por Shannon na sua obra. No seu entender, o verdadeiro problema da comunicação reside na reprodução, exacta ou aproximada, da informação seleccionada previamente por um emissor. Na medida em que o sucesso da emissão e recepção da mensagem provém da probabilidade da informação que nela está contida ser selecionada, a noção de informação encerra sempre processos estocásticos. Que algumas mensagens possuam sentido, que sejam providas de uma articulação conceptual, são dimensões semânticas «irrelevantes» para a questão técnica do processamento de informação, uma vez que o aspecto mais relevante é o de a mensagem actualizada ser o resultado final da discriminação efectuada entre as demais possíveis ${ }^{37}$.

Quer em Hartley quer em Shannon há uma aprioridade da função selectiva, circunscrita esta, porém, à esfera da emissão dos sinais e, dada a irrelevância a que o sentido se encontra votado, sem qualquer repercussão na esfera do receptor. É com o intento de ultrapassar o hiato entre informação e sentido que Donald MacKay propõe uma concepção semântica da comunicação. A aprioridade da selecção é similarmente partilhada pelo autor britânico $\mathrm{e}$, contrariamente às teorias precedentes, é aberta à esfera do agora receptor-intérprete. $\mathrm{O}$ sentido de um complexo comunicacional deve ser associado à sua «selective function» e não ao «effect» que dela pode derivar, isto é, aos seus produtos semânticos ${ }^{38}$. Luhmann concorda, genericamente, com esta ideia de Mackay. Mas, com ela, ainda não são dadas todas as implicações dos processos de formação de sentido. As remissões do sentido, que ocorrem dentro de um vasto espectro de possibilidades, implicam, necessariamente, operações de selecção. Segundo Luhmann, o sentido opera mediante esquemas de selecção face à complexidade do meio-ambiente de cada sistema, conferindo às remissões entre as diversas possibilidades dadas pelas vivências psíquicas e pela comunicação um ponto de ancoragem identitário, que vai ser manifestamente decisivo para a construção do primado de certas possibilidades sobre as demais ${ }^{39}$. Assim, se a configuração de uma informação é realizada através de uma operação de selecção, como Luhmann depreende

36 Weaver, "Recent contributions", 8.

37 Shannon, The mathematical theory, 31.

38 Donald MacKay, Information, Mechanism and Meaning (Cambridge, Massachusetts: The M.I.T. Press, 2nd Edition, 1972), 108.

39 Luhmann, Niklas, "Moderne Systemtheorien als Form gesamtgesellschaftlicher Analyse", in: Habermas, J./Luhmann, N., Theorie der Gesellschaft, 7-24, 12. 
da teoria da informação, isso significa que, nos casos em que uma operação de selecção é repetida, ela deixa de conter qualquer informação ${ }^{40}$.

De Hartley a MacKay há um percurso unidimensional da negação. Esta possui apenas uma função excludente. Na medida em que torna possível a selecção entre possibilidades de sentido, contribuindo, consequentemente, para a neutralização (inactualização) daquelas que são excluídas dos processos de actualização, a negação implica, desde logo, uma "generalização" dos elementos inactualizados. Com a inserção do sentido na articulação da informação (a constituição semântica), a negação ganha um novo estatuto operatório: em vez de contribuir, meramente, para a eliminação das possibilidades não-actualizadas, ela proporciona, de igual forma, a inclusão virtual destas últimas no horizonte dos possíveis. E é aqui, neste âmbito, que podemos falar de uma função inclusiva da negação. A subsistência virtual das possibilidades não-actualizadas - isto é, todas aquelas que preenchem o horizonte dos possíveis e das quais depende a continuidades das operações do sistema - está, em larga medida, conectada com o dispositivo "reflexivo" da própria negação. E graças a este que o inactualizado e o indeterminado podem ser reconvertidos em possibilidades actualizáveis. A reflexividade impõe-se quando a negação é capaz de actuar sobre si mesma - a negação da negação -, tornado assim exequível a recuperação das possibilidades subtraídas pela função excludente. Atribuir à negação unicamente uma função excludente tende a ser, ainda, uma consequência inevitável da ordem ontológica do tertium non datur. E tal consequência persiste, mesmo que se observe a negação já sob o prisma do sentido. F. H. Heinemann, por exemplo, no seu artigo The meaning of negation, distancia-se da tradicional divisão ontológica do real entre ser e não-ser, sustentando, contudo, que a interpretação do sentido só pode ser exposta de forma positiva ou negativa ${ }^{41}$. A questão que aqui impera está, mais uma vez, conectada com a redução do sentido à esfera da comunicação linguística, acusando o trabalho interpretativo apenas as formas adverbiais do "não" e do "sim".

40 Luhmann, Einführung, 124. O facto de, com a repetição da operação, deixar de haver informação, tal não implica uma eliminação do sentido que nela se actualizou. Pelo contrário. Como reitera Luhmann a respeito da informação "noticiosa": «Informationen lassen sich nicht wiederholen; sie werden, sobald sie Ereignis werden, zur Nichtinformation. Eine Nachricht, die ein zweites Mal gebracht wird, behält zwar ihren Sinn, verliert aber ihren Informationswert.» Niklas Luhmann, Die Realität der Massenmedien (Wiesbaden: VS Verlag für Sozialwissenschaften, 4. Aufl., 2009), 31. O processo (redundante) que conduz à Nichtinformation vai, por sua vez, potenciar a premência de novas informações veiculadas pelos mass media.

41 F. H. Heinemann, "The meaning of negation", in: Proceedings of the Aristotelian Society, New Series, Vol. 44 (1943-1944), 127-152, 147. 
É contra essa redução que devemos compreender a tridimensionalidade que apresenta o nexo sistémico "selecção-negação". Luhmann descreve três dimensões do sentido, que, tendo em conta o espectro dos possíveis, podem ser qualificadas como formas de articulação da selecção: i) "Dimensão factual" (Sachdimension): a distinção modelar entre System e Umwelt, que visa ultrapassar e substituir a polaridade epistemológica cartesiana "sujeito-objecto", aplica-se aos processos de selecção quer dos objectos das vivências psíquicas quer dos temas da comunicação. Dentro deste domínio, por exemplo, a determinação cognitiva de um fenómeno empírico implica sempre a negação de propriedades que não fazem parte da sua singularidade material. Contudo, este "não" deve ser entendido como um "ainda não", pois as propriedades remanescentes podem ser posteriormente actualizadas; ii) "Dimensão temporal" (Zeitdimension): as remissões relativas ao passado e futuro - ambos concebidos dentro da temporalidade do horizonte de possibilidades - são marcas temporais que constituem o presente afecto à actualidade dos eventos. Tais marcas indicam quer a observação da irreversibilidade dos eventos quer a possibilidade da sua reversibilidade; iii) "Dimensão social" (Sozialdimension): os processos de formação de sentido atingem uma conexão social quando se verifica uma selecção mútua - co-selecção, ou melhor, doppelte Selektivität $t^{42}$ - nos contextos de comunicação entre ego e alter. As operações de comunicação encerram vários processos selectivos. Às selecções da informação e da transmissão acresce a sua compreensão selectiva. Este último processo tenta estabelecer um equilíbrio funcional entre os dois processos anteriores, podendo, por isso, ocorrer escassa isomorfia entre ambos, como nos casos em que a transmissão apresenta um primado desmesurado sobre a informação. Para Peter Fuchs, que recorre ao mesmo esquema triádico proposto por Luhmann, a transmissão, sendo uma autêntica Ek-Stasis no interior das operações comunicacionais, torna-se igualmente decisiva para a observação que a comunicação faz de si mesma ${ }^{43}$. Contudo, sendo a comunicação o resultado irredutível da diferenciação dos três processos mencionados, a inexistência de qualquer compartimentação pode ditar a regressão do acto comunicativo a um mero acto perceptivo.

Da relação entre a dimensão social do sentido e o fenómeno da dupla contingência sobrevém o imperativo teórico da reformulação do próprio estatuto funcional do conceito de selecção. Sob a condição de dupla contingência, a corrente comunicativa que ocorre entre ego e alter redunda da escolha

42 Niklas Luhmann, Soziologische Aufklärung 2: Aufsätze zur Theorie der Gesellschaft (Wiesbaden: VS Verlag für Sozialwissenschaften, 5. Aufl., 2005) p. 104.

43 Peter Fuchs, Der Eigen-Sinn des Bewußtseins. Die Person, die Psyche, die Signatur, (Bielefeld: Transcript Verlag, 2003), 19-20. 
dos temas e do modo como um e outro são capazes de gerir as expectativas colocadas pelas operações de selecção. As possibilidades que, embora entrando no circuito de remissões de cada actualização do sentido, não são actualizadas, acabam por constituir centros de expectativas. Por consequência, a geração de expectativas é, na concepção luhmanniana, uma exigência que se apresenta ao próprio sistema, tendo em vista a detecção e organização de possibilidades ${ }^{44}$. Esta observação é basilar, pois dela também provém muitos dos elementos genésicos da complexidade afecta à dimensão social do sentido. Trata-se, em rigor, do nexo sistémico "selecção-negação" que maior complexidade acrescenta às dimensões do sentido, uma vez que a abrangência das possibilidades remanescentes ultrapassa os limites impostos pela pura dimensão factual. Como as possibilidades de sentido não são apenas privilégios de uma consciência isolada, mas antes inerentes à constelação ego-alter, as operações de selecção acusam uma natureza bidimensional ou, na terminologia luhmanniana, a selecção torna-se «duplamente selectiva» -, já que, previamente à selecção e actualização das possibilidades, torna-se imprescindível apurar o próprio «domínio da selecção» ${ }^{45}$. Com este primeiro acto selectivo são geradas pontes de comunicação entre ego e alter que ajudam a perspectivar, discriminar e reduzir as relações entre sistema e meio-ambiente.

Apesar da autonomia que as três dimensões do sentido evidenciam, elas não devem ser descritas como estáticas, desprovidas de qualquer co-operacionalidade dinâmica. Pelo contrário. Aquilo que numa dimensão específica pode ser objecto de actualização, tem, igualmente, capacidade de influenciar o grau de disponibilidade dos possíveis afecto às demais. Tal como usualmente acontece na dimensão social, o tema duma comunicação pode delimitar o espectro de possibilidades envolvido, por exemplo, na dimensão temporal.

\section{Negação e virtualização}

Nas operações de comunicação, a realização da distinção psíquico-sistémica entre ego e alter depende, segundo Luhmann, da negação do meio-ambiente que envolve cada um, isto é, do sistema psíquico que constitui o outro. Mas este é apenas o primeiro estádio da negação. A re-entrada da negação no sistema pressupõe uma virtualização da própria negação. Assim, como Luhmann formula a partir de uma expressão de Paul Valéry, o conceito

${ }^{44}$ Luhmann, Einführung, 124-125.

45 Luhmann, Soziale Systeme, 188-189. 
de dupla contingência implica sempre uma «double négation virtuelle» ${ }^{46}$, sendo, nessa exacta medida, a aceitação comunicacional do outro acompanhada pela possibilidade de ele devir diferente daquilo que é. Quer isto dizer que, para ser fixada sistemicamente, a negação obriga à sua virtualização no interior do sistema. Além de assegurar a continuidade das operações do sistema - neste caso, os processos de formação de sentido comunicacionais -, é também devido a esta inclusão virtual da negação que ego e alter geram e gerem, por assim dizer, o "grau de intensidade" da negação, já que a capacidade latente que ambos detêm para accionar o mecanismo da negação (Ich benutze meine Möglichkeiten des Negierens nicht, wenn Du Deine nicht benutz ${ }^{47}$ ) vai determinar a programação que emprestam ao binómio actual-virtual.

Ora, e como já foi intuído, a selecção põe em jogo múltiplas funções operatórias da negação. Estas são decisivas para que a formação de sentido possa ser pensada fora do espectro exíguo da identidade. Como nos diz a este respeito Gotthard Günther, «o sentido não é uma identidade, mas sim uma conexão (correlação) de dois componentes de sentido subalternos [como, por exemplo, "verdade" e "erro"], contendo, cada um, o outro como absoluta negação da sua própria determinidade reflexiva. ${ }^{48}$ Cada vivência psíquica e cada acto comunicativo são alimentados por várias possibilidades de sentido que, permitindo o contraste reflexivo entre si, asseguram a operacionalidade do sistema a que pertencem. Por isso, falar aqui de possibilidades é, antes de tudo, situá-las dentro de um vasto processo de diferenciação intra-sistémico que, enquanto tal, não pode ser meramente reduzido aos efeitos semânticos que cada possibilidade actualizada permite.

Apoiado na concepção husserliana de Horizontstruktur der Erfahrung, que prevê no espaço experiencial a co-existência dos possíveis ${ }^{49}$, Luhmann parte da premissa de que qualquer acto de identificação - exemplo: a apreensão cognitiva de um objecto ou evento - é dado dentro de um horizonte de remissões. Consequentemente, as possibilidades que não são integradas

46 Niklas Luhmann, "Systemtheoretischen Argumentationen. Eine Entgegnung auf Jürgen Habermas", In: Habermas, J./Luhmann, N., Theorie der Gesellschaft, 291-404, 323-324. A Expressão de Valéry encontra-se em Animalités, Ouevres, Bd I (Paris: Éd. La Pléiade, 1957), 402.

47 Niklas Luhmann, Soziologische Aufklärung 3: Soziales System, Gesellschaft, Organisation (Wiesbaden, VS Verlag für Sozialwissenschaften, 4. Aufl., 2005), p. 50.

48 Gotthard Günther, "Metaphysik, Logik und die Theorie der Reflexion", in: Beiträge zur Grundlegung einer operationsfähigen Dialektik, Erster Band (Hamburg: Felix Meiner Verlag, 1976), 31-74, 64.

49 Vide, por exemplo, Edmund Husserl, Erfahrung und Urteil: Untersuchungen zur Genealogie der Logik, Ausg. und Hrsg. von Ludwig Landgrebe (Prag: Academia Verlagsbuchhandlung, 1939), §§ 8-9, 26-37. 
em cada acto de selecção não são meramente eliminadas, mas antes neutralizadas, isto é, a continuidade dos processos selectivos sistémicos depende sempre de o mundo permanecer como «horizonte de remissão a outras possibilidades ${ }^{50}$. Por outro lado, como reitera Luhmann, esta abertura à contingência dos possíveis mostra-se capital para o reforço da própria selectividade. ${ }^{51} \mathrm{E}$ é esse mesmo horizonte de possibilidades que, paralelamente, leva «o sistema a experienciar a resistência da realidade» (Widerstand der Realität $)^{52}$. Se é lícito inferir que a ideia de "resistência" transporta o pressuposto do acesso ao real, também é verdade que o espaço onde se move a resistência é um Zwischenraum, capaz de gerar centros de tensão entre as diversas operações do próprio sistema - entre operações de comunicação e operações de comunicação, entre operações da consciência e operações da consciência ${ }^{53}$.

A negação afigura-se, assim, como condição fundamental para a formação de sentido, nomeadamente para que cada acto de selecção seja incluído na constituição do horizonte dos possíveis. Neste âmbito, o remanescente de qualquer selecção é, em termos quantitativos, sempre superior ao actualizado. Como bem demonstra uma das asserções mais repetidas por Luhmann, jedes Ja impliziert mehr Neins. Daqui sobrevém, precisamente, o positivo carácter sistémico da negação. Poder-se-á com razão afirmar que o desempenho da negação visa não só tornar possível a selecção entre possibilidades de sentido, como também permite a divisão destas sob o prisma do binómio "actual-virtual". As duas funções da negação anteriormente descritas (função excludente e função inclusiva) deixam-se, por isso, consubstanciar numa terceira - a qual denominamos de função disjuntiva. Esta actua em duas direcções vitais. Ao mesmo tempo que preserva e potencia a distinção entre possibilidades actualizadas e possibilidades inactualizadas ${ }^{54}$, é também

50 Luhmann, Moderne Systemtheorien, 12.

51 Ibidem.

52 Luhmann, Die Wissenschaft der Gesellschaft, 369.

53 Niklas Luhmann, Die Kunst der Gesellschaft (Frankfurt am Main: Suhrkamp Verlag, 1995), 504.

54 No que aos fenómenos da percepção diz respeito, Alfred North Whitehead, em Process and Reality, dá-nos uma visão assaz ilustrativa desta distinção operada pela negação. O filósofo encontra nas possibilidades inactualizadas o fundamento da percepção consciente, mostrando, por outro lado, que é através do "feeling of negation" - e, no caso da consciência, trata-se de um "intellectual feeling", já que radica no contraste entre afirmação e negação - que a consciência revela os seus graus de individuação. O exemplo seguinte é assaz ilustrativo desta concepção: «The general case of conscious perception is the negative perception, namely, 'perceiving this tone as not grey'. The 'grey' then has ingression in its full character of a conceptual novelty, illustrating an alternative. In the positive case, 'perceiving this stone as grey', the grey has ingression in its character of a 
responsável pela estabilidade da bimodalização "actual-virtual" que sustenta a operacionalidade do sentido. É através deste cariz positivo da negação que a virtualização é exequível, pois, caso contrário - mormente se a negação tivesse uma função única e exclusivamente eliminativa -, não seria possível sustentar teoricamente a latência das possibilidades inactualizadas. Deste modo, uma definição de "sentido" implica sempre o reconhecimento da dupla inclusão de actualidade e virtualidade, como, aliás, se pode inferir da seguinte formulação de Luhmann: «O sentido é a actualização contínua de possibilidades. Como o sentido apenas pode constituir sentido como diferença actual dentro do horizonte de possibilidades, qualquer actualização conduz sempre à virtualização das possibilidades que nela se encontram.» $\mathrm{E}$, com o intuito de enfatizar a natureza auto-referencial do super-médium sentido, o autor acrescenta: «A diferença entre actualidade e possibilidade permite, nesse aspecto, uma utilização deslocada temporalmente e, com ela, o processamento da actualidade respectiva no contexto das manifestações de possibilidades. Logo, o sentido é a unidade de actualização e virtualização, de re-actualização e re-virtualização, entendido como um processo que se estimula a si próprio (capaz de ser condicionado através de sistemas).» ${ }^{55}$

Embora a virtualidade possua uma dimensão pré-linguística, a sua repercussão, no interior dos sistemas, está sujeita às dinâmicas incutidas pela evolução e especificidade de cada médium comunicacional. Luhmann, ao assinalar as mudanças sistémicas provocadas pela transição da "sociedade estratificada" para a "sociedade diferenciada funcionalmente", serve-se das transformações operadas na linguagem pela imprensa. A disseminação e a reprodução da palavra escrita vão promover novos estádios de virtualização. Segundo o autor, o aparecimento da escrita veio já desencadear «uma nova presença do tempo», porque suportada pela «ilusão da simultaneidade do que não é simultâneo»; quer dizer, o «tempo virtual do passado e do futuro devém contemporâneo do presente» ${ }^{56}$. O resultado destas mudanças radi-

possible novelty, but in fact by its conformity emphasizing the dative grey, blindly felt. Consciousness is the feeling of negation: in the perception of 'the stone as grey', such feeling is in barest germ; in the perception of 'the stone as not grey', such feeling is in full development. Thus the negative perception is the triumph of consciousness. It finally rises to the peak of free imagination, in which the conceptual novelties search through a universe in which they are not datively exemplified.» Alfred North Whitehead, Process and Reality, Corrected Edition, Edited by David Ray Griffin and Donald W. Sherburne (New York: Simon and Schuster, 2010), 161. O itálico é meu.

55 Luhmann, Soziale Systeme, 100.

56 Luhmann, Die Gesellschaft der Gesellschaft, Band I, 265. Segundo Luhmann, com a invenção da escrita desencadeiam-se novas possibilidades sistémicas que são introduzidas no âmago da comunicação. Uma dessas possibilidades pode ser caracterizada como potencialização da "formação de opinião" e suas consequências para a organização social. 
cais operadas pela escrita traduz-se num incremento da informação face à comunicação. Com a imprensa, porém, os processos de estandardização da linguagem vão acompanhar os processos de individuação da comunicação, desenvolvendo-se, paralelamente, novos registos mnemotécnicos da própria sociedade. Por outro lado, se se partir da premissa de que o sentido é na unidade da diferença entre actualidade e virtualidade, então, como nos diz Luhmann, «a escrita pode ser interpretada como uma enorme expansão do campo da virtualidade», já que o ler e o escrever, emancipando-se da pressão social e da comunicação presencial, permitem uma crescente apreensão dos «aspectos virtuais» do sentido ${ }^{57}$.

O incremento da informação e a consequente ampliação do virtual são processos que acabaram por definir a constituição dos novos media digitais. Ainda que Luhmann não desenvolva detalhadamente as relações entre o super-médium computador e a sociedade, pois a sua analítica da sociedade moderna está essencialmente apoiada nos médiuns pré-digitais, há, no entanto, portas teóricas relevantes na obra Die Gesellschaft der Gesellschaft que indiciam uma certa abertura à questão das novas tecnologias digitais e aos seus efeitos sistémicos. A guiar as formulações de Luhmann sobre o super-médium encontra-se a ideia de "controlo", herdada da cibernética, e a reconfiguração da relação tradicional "figura-fundo". E isto em dois momentos indissociáveis: quer na interacção entre informação e utilizador quer na interacção entre utilizador e ecrã. Por um lado, o utilizador pode aceder a dados que, embora determinados pelas redes de informação, têm uma cartografia global. O controlo que aqui é facultado ao utilizador deriva da possibilidade de o super-médium responder aos seus comandos. Mas, por outro lado, este

Mas esta potencialização não se deixa contextualizar apenas nas práticas de comunicação. Ela vai, no entender de Luhmann, alastrar ao património semântico da sociedade - «a semântica, no seu todo, é 'modalizada'» (Ibidem, 277). O que implica que a visão do real deixa de ser apenas guiada pelo binarismo necessidade-contingência, dando cada vez mais espaço ao espectro dos possíveis, do qual se infere, por exemplo, a genealogia das narrativas utópicas e do fantástico romanesco (Ibidem, 278). Convém aqui referir que o termo "semântica" é utilizado por Luhmann para designar um estádio do sentido que está menos sujeito aos contextos de actualização do sentido das vivências comunicativas e psíquicas. É dessa forma que se presta à função de estabilizar e generalizar, por exemplo, certos pontos de observação e certas formas de expressão (linguísticas, entre outras). De um ponto de vista evolutivo, Luhmann defende a tese de que os desenvolvimentos estruturais sociais tendem a gerar «correlatos semânticos», como foi o caso do florescimento do pensamento filosófico na Grécia Antiga com o desenvolvimento das estruturas da cidade-estado. Niklas Luhmann, Gesellschaftsstruktur und Semantik. Studien zur Wissenssoziologie der modernen Gesellschaft, Band I (Frankfurt am Main: Suhrkamp Verlag, 1980), 36.

57 Niklas Luhmann, Die Religion der Gesellschaft (Frankfurt am Main: Suhrkamp Verlag, 2000), 258. 
controlo operatório dado pelo ecrã parece desvanecer quando o utilizador se vê impossibilitado de observar as próprias operações internas da máquina (o software), isto é, o controlo do utilizador é, por assim dizer, um controlo à superfície, porque lhe é restrito o acesso ao fundo da máquina. Este, como reitera Luhmann, «permanece invisível» ${ }^{58}$. A expressão "realidade virtual" - no sentido de virtus - apenas serve aqui para designar o acoplamento operatório entre superfície e fundo, que está dependente das operações de actualização levadas a cabo pelos utilizadores. Que estas operações computacionais ampliem o espaço dos possíveis e redobrem os momentos de virtualização, pois permitem um extenso campo de distinções e designações, é, para Luhmann, um facto insofismável, que nos coloca perante a questão da sua repercussão para os sistemas de sentido apoiados na comunicação.

Com efeito, tal como nos sugerem as operações mediadas digitalmente, aquilo que não é actualizável - as possibilidades excluídas - não é necessariamente eliminado, mas antes, como refere Luhmann, sujeito a um «estado de inactualidade momentânea» ${ }^{59}$. O que significa, por outro lado, que pode ser ("pode ser" porque a recursividade sistémica encontra-se sob a égide da actualidade e, neste aspecto, nem tudo tem de recorrer) introduzido em novos horizontes de possibilidades, já que, e como refere um dos autores citados por Luhmann, «aquilo que é actualizado potencializa outra coisa ${ }^{60}$. Como já tínhamos visto, convém aqui acentuar o facto de que as operações dos sistemas de sentido são sempre dadas na sua actualização. Daqui também redunda a inevitável impossibilidade de estes sistemas «operarem potencialmente ${ }^{61}$. Todavia, com o incremento de complexidade nas operações de diferenciação suportadas pelo binómio "actual-virtual", há, paralelamente, formas de possibilidades que melhor acusam o primado da virtualidade no interior do sistema. Trata-se de possibilidades com um grau de especulação elevado, como, por exemplo, aquelas relativas à antecipação

58 Luhmann, Die Gesellschaft der Gesellschaft, Band I, 304. Poder-se-á ver nesta invisibilidade uma analogia com a impossibilidade de haver uma visão total do mundo. Tal como o software do computador permanece vedado à nossa percepção, também o mundo - compreendido como virtuelle Realität, como espaço inesgotável dos possíveis ainda não actualizados - se mostra incapaz de ser submetido a uma objectivação que, independente da observação, pudesse, simultaneamente, actualizar os correlatos virtuais das operações mediadas pelo sentido. Sobre isto, vide Dirk Baecker, "Niklas Luhmann in der Gesellschaft der Computer", in: Wozu Soziologie? (Berlin: Kulturverlag Kadmos, 2004), 125-149.

59 Luhmann, Soziale Systeme, 101.

60 Yves Barel, Le paradoxe et le système: essai sur le fantastique social (Grenoble: Presses Universitaires de Grenoble, 1979), 186.

61 Luhmann, Die Kunst der Gesellschaft, 225. 
e previsão de eventos ${ }^{62}$. A organização de informação adoptada pelos media da imprensa, estando duplamente ligada à pressão selectiva e à redução da complexidade, revela-nos critérios de selecção que acusam, de forma assaz ilustrativa, muitos destes efeitos do virtual sobre o actual (e vice-versa). Considerando, com Luhmann, os critérios de selecção da imprensa, poder-se-á dizer que destes sobressai uma espécie de equilíbrio funcional imposto aos processos selectivos, cuja natureza assenta em dois modos diversos de processar a formação de sentido: a selecção da informação obedece a critérios que tanto põem em jogo a multiplicação dos possíveis - o primado da virtualidade - como o seu processo inverso - o primado da actualidade. No primeiro caso, as novidades, os conflitos e os escândalos são temas de comunicação que favorecem os efeitos de "surpresa", "excitação" e "estupefacção". As possibilidades de sentido que estes temas envolvem são exponencialmente potenciadas, conduzindo, muitas vezes, os intérpretes da informação ao plano da adivinhação. No segundo caso - a redução dos possíveis -, a selecção da informação é orientada pelo imperativo de actualidade. Geralmente são os acontecimentos irreversíveis, como, por exemplo, factos trágicos, que são utilizados com o intuito de gerar uma série de eventos similares e, através desse método de seriação, oferecer uma visão temporal, determinada e limitada, da realidade ${ }^{63}$.

A premissa apresentada anteriormente - a impossibilidade dos sistemas psíquicos e sociais operarem potencialmente - não deve, por isso, supor uma mera subordinação da esfera dos possíveis aos processos de actualização. Pelo contrário. Aquilo que é actualizado envolve sempre uma reportação à esfera dos possíveis, uma vez que a distinção actual-virtual re-entra em cada operação de selecção levada a cabo pelo sistema ${ }^{64}$. Ou seja, a re-entrada é conditio sine qua non para a autopoiese do sentido, para a reprodução do sentido como sentido. Aludindo ainda a este fenómeno da re-entrada, torna-se igualmente inevitável dele inferir que o remanescente de cada selecção apenas se constitui como horizonte de possibilidades se for re-virtualizado sistemicamente, isto é, os possíveis que configuram o espectro do potencial estão dependentes da sua actualização (enquanto possíveis virtualizados) nas próprias operações do sistema. Caso tal não se verifique, o sistema deixa de os poder incluir nas suas operações e, estando eles sujeitos à erosão temporal, podem ser verdadeiramente eliminados do espectro do potencial. Embora tantas vezes aplicada na ilustração do conceito de virtualidade, a "metáfora da semente" não é, neste caso, teoricamente compatível com o factor temporal. $\mathrm{O}$ facto de os processos de virtualização estarem acoplados

\footnotetext{
62 Luhmann, Die Wissenschaft der Gesellschaft, 683.

63 Luhmann, Die Realität der Massmedien, 42-49.

64 Luhmann, Die Kunst der Gesellschaft, 174.
} 
à esfera da actualidade impede-nos de conceber um pretenso domínio da virtualidade autónomo e, por consequência, indiferente à determinação das operações selectivas. Com a re-virtualização de uma determinada possibilidade anteriormente inactualizada - mormente quando a mesma acusa o facto de ter sido preterida, mais do que uma vez, da esfera da actualidade - é gerado, por assim dizer, um registo mnésico operatório mais consubstanciado na função excludente da negação do que, propriamente, na sua função inclusiva. Tal como sucede no mundo orgânico - e se quisermos fazer bom uso da "metáfora da semente" -, também a semente acaba por ser determinada pela planta, ao ponto de, não raras vezes, perder a sua eficiência germinal.

\section{Conclusão}

Ao permitir sustentar, no interior do sistema, a distinção entre actual e virtual, ou, com um alcance mais geral, as próprias operações auto-referenciais sistémicas - visto que, como refere Luhmann, «o sistema também evoca aquilo que ele mesmo já tinha excluído» ${ }^{65}$-, a negação vai igualmente contribuir para a redução e conservação da complexidade do mundo. Num dos parágrafos da obra Soziale Systeme, podemos encontrar uma analogia ilustrativa da relevância da negação para o registo autopoiético dos sistemas apoiados na formação de sentido. Luhmann recorre ao sistema imunológico dos organismos para mostrar que, tanto os sistemas sociais quanto os sistemas psíquicos, "se imunizam não contra o não, mas antes com a ajuda do não» ${ }^{66}$. Neste aspecto, e uma vez que a analogia salienta a importância funcional da negação para a autopoiese dos dois sistemas, este facto levar-nos-ia a desenvolver uma «lógica imunológica», capaz de reinscrever o papel inclusivo da negação nas operações mediadas pelo sentido; tarefa essa, no entanto, que Luhmann rejeita prosseguir, visto que a lógica dos sistemas sociais é cabalmente incompatível com o princípio de "estabilidade" que rege a preservação da vida orgânica ${ }^{67}$. A "instabilidade" é, inversamente, o referente lógico das operações comunicacionais que suportam a autopoiesis dos sistemas sociais. Da instabilidade podemos dizer, com Luhmann, que ela redunda da bipolarização da realidade, já que através da comunicação são geradas duas versões contíguas - uma «versão-sim» e uma «versão-não» - do universo de possíveis, cujo efeito se manifesta na pressão selectiva e,

65 Niklas Luhmann, Das Recht der Gesellschaft (Frankfurt am Main: Suhrkamp Verlag, 1993), 43, Nota de rodapé 12.

66 Luhmann, Soziale Systeme, p. 507.

67 Ibidem. 
com esta, no próprio registo autopoiético dos sistemas sociais ${ }^{68}$. Uma vez que os sistemas apoiados no sentido dependem de um vasto repertório de possibilidades, eles podem ser observados e caracterizados a partir da sua existência paradoxal, que, como se intentou evidenciar, decorre do facto de as possibilidades não-actualizadas contribuírem para o desenvolvimento das suas operações - numa palavra, eles vivem daquilo que ainda não são.

\section{COMENTÁRIOS}

\section{Comentário I}

\section{Edmundo Balsemão Pires}

O artigo de Joaquim Braga vem publicar os estudos de problemas epistemológicos sobre Teoria dos Sistemas Sociais desenvolvidos no quadro da pesquisa do grupo de investigação sobre a "Individuação da Sociedade Moderna" da unidade de investigação de Filosofia de Coimbra (LIF). O presente texto desenvolveu-se a partir de uma comunicação apresentada num seminário deste grupo e aí discutido.

Os recentes desenvolvimentos transdisciplinares na "ciência de segunda ordem" do que E. von Glasersfeld e outros baptizaram na expressão "construtivismo radical" veio devolver à ordem do dia o exame dos pressupostos teóricos da Teoria dos Sistemas. Para muitos, o "construtivismo" oferecia apenas a linguagem conveniente para um conjunto de preocupações partilhadas nas várias disciplinas que recorriam aos sistemas como modelos de inteligibilidade. Mas o problema primitivo é logo o de saber que tipo de inteligibilidade é o sistémico. Há realidades no mundo que os sistemas esclarecem mas que subsistem sem eles? Formulada neste estilo ingénuo, esta pergunta resume uma das dificuldades que se colocam aos modelos epistemológicos que põem a tónica na dimensão operatória da emergência da cognição e, por isso, supõem o traçado da linha de fronteira entre formas $\mid$ meios ou sistema $\mid$ meio-ambiente. Joaquim Braga toma como referente o formato teórico proposto por Niklas Luhmann.

Nos seus rudimentos, a Epistemologia construtivista pode reconstruir-se nas proposições nucleares do que H. von Foerster chamou Teorema 1 de H. Maturana, que afirma que "anything said is said by an observer", a que acrescentou a tese "anything said is said to an observer". Ambas as asserções colocam sob a responsabilidade de observadores finitos e limitados nas suas capacidades cognitivas a fonte do que se diz nos juízos. O dizer não afigura nenhuma realidade mas exprime o que um observador faz ao dizer, como concebe o conteúdo do que diz. Ora, o significado do que o observador diz se articula com o que outros que igualmente observam conseguem perceber do dito. $\mathrm{O}$ teorema e a tese não concebem a observação como um

68 Luhmann, Aufsätze, 104. 
registo passivo de acontecimentos mas não são uma outra formulação de um mesmo "linguistic turn", embora essa impressão possa decorrer do que afirma H. Maturana sobre o "Languaging". A observação não é um estado mental reprodutor mas um fazer inscrito numa rede de relações e funções operatórias que define as circunstâncias ecológicas da observação. Por outro lado, o que o próprio H. Von Foerster designou por "Cibernética de segunda ordem" exprime a retomada ("re-entry", G. Spencer-Brown) da forma da observação em outra observação. Esta é uma consequência que vem sendo cada vez mais salientada. A cognição não é um acumular de informação, mas constituição de formas e re-entrada de formas em outras. Isto é: o observador deixa apropriar a sua posição cognitiva sobre o mundo por outras posições de outros observadores assim se gerando discurso sobre observações e Ciência no sentido mais próprio. Em consequência da rotação do interesse para as operações no lugar de objectos e para as retomadas das observações a teoria construtivista da cognição fornece o horizonte epistemológico para desenvolver meta-teorias sobre temas tais como a estrutura autorreferencial do cérebro, a forma de rede da organização neuronal, a auto-organização e a emergência em sistemas biológicos, psíquicos e sociais, ou o estudo dos fenómenos de retomada da linha de fronteira do sistema no sistema e de formação de reflexos antecipatórios em máquinas não-lineares (sistemas vivos, psíquicos e sociais). A obra de N. Luhmann inscreveu-se nesta linha da Epistemologia construtivista, explicitamente desde Sistemas Sociais (1984) e foi isso que trouxe originalidade à sua teoria sociológica dos sistemas sociais.

Em consequência da viragem construtivista duas preferências analíticas e temáticas se consolidam: a sequencialidade do encadeamento dos elementos dos sistemas e a formação da auto-referência dos sistemas.

O artigo de Joaquim Braga é uma ilustração da relação interna destes dois focos analíticos, à luz da exploração dos conceitos nucleares de negação e virtualização. $\mathrm{O}$ seu estudo supõe algum conhecimento do alcance do teorema 1 de H. Maturana e da tese complementar de H. Von Foerster no que a Teoria dos Sistemas de N. Luhmann chamou "observação de segunda ordem". Sem o movimento da primeira na segunda ordem observacional o âmbito da formação da latência | virtualização é somente incoativo.

O artigo retoma a "teoria matemática da comunicação" como uma das fontes do conceito luhmanniano de sentido, situando a componente informação na tríade definidora do sentido informação, mensagem e compreensão de Sistemas Sociais. Aí já está presente a relação sequência | selecção | negação e a distinção actual | potencial, que vem aliás do encontro com a Fenomenologia de Husserl de finais de 1960. Se o sentido é uma estrutura de selecções não pode deixar de operar segundo uma moldura modal em que situamos a fronteira do actual | potencial. A teoria dos sistemas tem aqui um valor inestimável para a renovação das teorias modais tão sobrecarregadas com uma antiquada Metafísica.

Um desafio é desenvolver a ideia de que a sequencialidade sistémica propulsiona as re-entradas, como os trabalhos de Louis Kauffman mostraram a partir de G. 
Spencer-Brown, e confirma assim a auto-referência do lado marcado. É de esperar que um estudo sistémico da repetição e da memória possa aqui trazer esclarecimento. Só a memória situa o cruzamento entre conservação das selecções, virtualização e negação. Neste artigo, a relação com o tema da memória está anunciada. O encontro com a Psicanálise, a respeito da Verneinung, e com teses da Psicologia Cognitiva vai elucidar se a Cognição é um sistema autónomo das três máquinas não-lineares (sistemas) ou não. Se nos inclinarmos mais para esta resposta isso não impede que se usem analogamente noções como memória, inteligência, aprendizagem, conservação das selecções, etc., relativamente a sistemas distintos. Significa que podemos estudar algo como a forma geral da cognição e isolar nela algumas funções características, mesmo sabendo que o que opera cognitivamente são sempre sistemas dotados de elementos concretos de um tipo biológico, psíquico ou social e tendo em conta que o tipo concreto de elementos pode exigir especificações do estatuto geral do que chamámos cognição. Podemos usar transversalmente noções como re-entrada, memória, negação, selecção ou aprendizagem mas somos compelidos a entrar em detalhes sobre os elementos que operam tais funções cognitivas. Estas clarificações são relevantes na medida em que ainda hoje há incompreensões resultantes de não se compreender de que se fala quando se aplicam categorias cognitivas a sistemas cujos elementos não são psíquicos.

\section{Comentário II}

\section{Cláudio Alexandre S. Carvalho}

Com o objectivo de compreender o papel epistémico e operatório dos conceitos de negatividade e virtualidade no pensamento de Niklas Luhmann, em seu artigo Joaquim Braga passa em revista algumas das influências (lógicas, matemáticas, e cibernéticas) que vertebraram as profícuas aplicações da Teoria dos Sistemas. Aqueles dois conceitos estão na base dos processos selectivos que caracterizam a autopoiésis e os diferentes acoplamentos dos sistemas baseados no sentido (comunicativos e psíquicos) e, como tal, permitem entrever os novos desafios que se apresentam aos herdeiros do legado de Luhmann. Isso é claro sobretudo no tocante às repercussões que têm para a concepção de cognição (entre outras) a evolução não só dos próprios meios de comunicação em sentido estrito, mas também da técnica. Da alteração acelerada destes factores decorre o surgimento de novas possibilidades da dinâmica da auto-organização do sistema psíquico, mas também dos sistemas sociais, aumentando não só a complexidade dos respectivos meios mas também a contingência na sequência das selecções, levando por um lado a uma maior pressão selectiva, por outro ao emergir de novas formas de re-entrada e controlo das suas operações.

Além da crítica à manutenção da metafísica substancialista como fundamento dos diferentes saberes, a teoria da observação de segunda ordem como base descritiva dos diferentes sistemas da sociedade funcionalmente diferenciada, permitiu a Luhmann descrever e problematizar a autonomia da comunicação frente às opera- 
ções dos sistemas psíquicos. É na linguagem que encontramos um medium exterior comum a sistemas psíquicos e comunicativos. Contudo, não é demais sublinhar, como o faz Joaquim Braga, a natureza parcialmente pré-linguística do sentido, notória não só no domínio da percepção mas também nas operações subjacentes ao encadeamento da comunicação. A operação de negação tem, como assinala o autor, um papel preponderante pois permite acompanhar os mecanismos de diferenciação dos sistemas (não só o psíquico mas também o comunicativo), sobretudo a partir do mecanismo de reentrada da forma na forma. A negação, tal como na melhor tradição filosófica e psicanalítica, não é terminante, sendo que o excluído não só tem um papel no "histórico" e no reforço (ou dissolução) da identidade, mas fica disponível para futuras selecções, não enquanto "tal", mas em função da própria modalidade em que é tomado. A virtualidade em Luhmann refere uma latência entre "algo" que, num determinado momento, permanece em potência a partir da actualização da selecção e das regras internas, mas cuja "realidade" só pode ser concebida em função da sua configuração compatível com a "sensibilidade" daquele sistema. Sem esta ancoragem não existiria virtualidade mas puro caos. $\mathrm{O}$ sistema constitui-se a partir de um encerramento operacional, mas sempre preservando uma abertura cognitiva que conforma determinados limites para a surpresa, além dos quais é possível a sua dissolução.

Mas, se a virtualidade só adquire "forma" e consistência a partir da observação de segunda ordem, capaz de tematizar as possibilidades não actualizadas em sua densidade, é de difícil esclarecer se a virtualidade decorre forçosamente da operação de negação. Na transição para a sociedade funcionalmente diferenciada, marcada pelo gradual decair da objectividade dos antigos códigos, as novas formas de auto-descrição da sociedade, libertas da pressão do costume e do modelo da comunicação entre copresentes, vão apresentar soluções ainda não admitidas na semântica, mas nas quais se encontrarão algumas das soluções que permitem a resolução de bloqueios e/ou contradições dos sistemas. Esses mecanismos pré-adaptativos tinham justamente um valor virtual na medida em que, ao serem tematizados, permitiam antever novas formas não só de conter, mas também de abarcar e mobilizar a contingência, de, por assim dizer, encontrar as suas fontes de irritação selectas.

Deve notar-se que, mesmo em sistemas sob o primado da estabilidade, como é o caso dos biológicos, não é possível falar em "adaptação ao meio" pois a recursividade do sistema se apoia numa selectividade sempre transitória. Nos sistemas baseados no processamento do sentido, a importância da selecção é proporcional à ordem de selecções possíveis, inerentes às possibilidades de re-entrada da diferença (face ao meio) na diferença. O sentido opera nos diferentes sistemas mediante a emergência de esquemas ou padrões de selecção que, restringindo o possível, estabelecem para as operações comunicativas e psíquicas um ponto de referência comum.

A situação de "dupla contingência", que Luhmann começa a conceber ainda nos anos 60 valorizando o valor dos contra-factuais na antecipação do comportamento de alter, é essencial pois permite aceder à "concretização" e reprodução comunicativas 
dos diferentes códigos simbolicamente generalizados, sobretudo à estabilização das expectativas. Se bem que a estrutura lógica que suporta este mecanismo tenha sido abordada por Joaquim Braga, a mesma presta-se a um desenvolvimento do código binário na base dos diferentes sistemas sociais. Mesmo tendo em conta as projecções semânticas de que se revestem, enquanto meios de comunicação generalizados do ponto de vista simbólico, são os códigos de base nos diversos sistemas da sociedade moderna que vem a sincopar as operações de reentrada, figurando em Luhmann como complemento essencial da teoria da distinção com base em Spencer-Brown. É também neste âmbito que ganha "concretude" a concepção de uma "função disjuntiva" da negação, que Braga mostra ir além das funções excludente e inclusiva.

Iniciando a sua leitura na obra de 1984 (Soziale Systeme), Joaquim Braga nota a importância crescente que assumem para Luhmann as tecnologias digitais e respectivas formas de interacção baseadas na dinâmica superfície-profundidade. É neste âmbito que, mesmo compreendendo a crítica aos modelos teóricos apoiados numa oposição estrita de real-irreal, a "marginalização digital" com que abre o artigo foi bastante atenuada nas últimas duas décadas. É ao nível dos recentes avanços na tecnologia digital que surgem novos desafios suscitados pela criação de novas interfaces -não mais limitadas a um contacto de "superfície"- que se desenvolvem não só modelos de cognição incorporada relativos ao sistema psíquicos, mas também novas aplicações dos meios e códigos comunicativos de diferentes sistemas, pondo o foco na importância dos processos selectivos que têm lugar em cada um dos meios. Os acoplamentos estruturais abrem-se aí a novas formas de observação da recursividade do sistema, da sua aquisição de memória e aprendizagens, as quais reforçam e modulam a identidades dos sistemas envolvidos, permitindo também mecanismos de controlo e reescrita da sensibilidade e das regras internas que regem a reprodução do sistema. É possível afirmar que a reflexividade que caracteriza a negação e a dinâmica própria da virtualidade propostas por Luhmann, assumem um papel de destaque nessa nova compreensão da cognição concebida como processo temporal marcado por uma actividade não linear e inserida em redes complexas.

\section{Comentário III}

\section{João Pedro Cachopo}

No artigo "Negação e virtualização em Niklas Luhmann", Joaquim Braga procura esclarecer, na sua complexidade e articulação, vários aspectos da teoria dos sistemas do sociólogo alemão falecido em 1998, cujo trabalho sobre os processos de formação de sentido psicológicos e sociais é consabidamente célebre. A relação entre os conceitos de negação e virtualização, e o papel decisivo, se não matricial, do primeiro para uma compreensão adequada do modus operandi do segundo, merecem-lhe particular atenção. $\mathrm{O}$ texto, à semelhança do corpus teórico sobre o qual se debruça, não se presta a simplificações. Apesar disto - ou, melhor dito, em virtude disto - é lícito afirmar que o artigo não fica aquém daquilo a que se propõe, 
pois não se limita a destrinçar certos nexos de uma obra particularmente intrincada, mas fá-lo, a cada passo, sem escamotear a complexidade do todo.

Neste sentido, trata-se de um texto capaz de captar a atenção quer do leitor empenhado em aprofundar o seu conhecimento acerca da obra de Luhmann, ou em cotejar a sua própria visão sobre ela com a do autor do texto, quer do leitor interessado em explorar mais livremente os temas e problemas por ele abordados. O primeiro destes leitores encontrará matéria de discussão em torno de aspectos da obra luhmanniana que vão desde os conceitos de sistema, ambiente [Umwelt] e mundo [Welt] ou das dimensões factual, temporal e social do sentido até à teoria da observação de segunda ordem, passando pelo cruzamento com os contributos de Frege ou Freud para a complexificação do conceito de negação.

Se um relance de olhar sobre as diferentes etapas deste texto me permite evocar estes tópicos, o facto de me querer esquivar a um mero exercício de paráfrase, por um lado, e, por outro lado, a circunstância de pretender alargar a discussão em direcções menos previsíveis, levam-me a fazer coincidir este comentário com um convite à leitura. Fá-lo-ei em torno de três observações: a primeira expressa um interesse e uma intuição; a segunda uma dúvida, talvez uma reticência; a terceira uma hipótese acerca da disseminação da obra de Luhmann.

(1) Começo, assim sendo, por me referir a um dos aspectos que julgo poder animar um desdobramento produtivo da obra luhmanniana no campo da estética: a possibilidade de discernir a especificidade da constelação formada por práticas, objectos e discursos artísticos, enquanto sistema social, nos termos da sua valência enquanto ponto de observação privilegiado das "dinâmicas traçadas pela contingência e pela complexidade".

O que aqui intuímos é a possibilidade de a arquitectura da teoria dos sistemas não obstaculizar de todo, e poder até fomentar, um entendimento estético-político da arte mais ambicioso do que uma abordagem meramente descritiva admitiria. O mundo da arte, mais do que qualquer outro, permitiria mostrar que, como escreve Luhmann em Schriften zu Kunst und Literatur, nenhuma realidade pode excluir a possibilidade de devir diferente. O conceito de virtual é neste ponto decisivo: é ele que dá consistência sistémica ao "excedente" de possíveis negados (i.e., não seleccionados). E é em torno dele - e, em particular, da sua relação com o conceito de negação, e da distinção entre as funções excludente e inclusiva deste último - que gira a questão em que consiste a minha segunda observação.

(2) Ao longo do artigo, acentua-se que a negação - sem o que, aliás, não se compreenderia a sua relação com a virtualização e com o binómio virtual/actual - opera por selecção, não tanto eliminando quanto preterindo possibilidades. A não-selecção de uma possibilidade não permite atribuir uma função meramente excludente à negação, pois dessa não-selecção decorre, não uma anulação, mas uma latência. Por outras palavras, a negação tem também uma função inclusiva, que espoleta a operacionalidade a um só tempo autopoiética e reflexiva do sistema. 
A minha questão neste contexto é a de saber até que ponto é indispensável interpretar a reflexividade que caracteriza todo este processo em termos ostensivamente hegelianos. Dá ensejo a esta questão o seguinte passo: "A reflexividade impõe-se quando a negação é capaz de actuar sobre si mesma - a negação da negação -, tornando assim exequível a recuperação das possibilidades subtraídas pela função excludente". À luz da crítica dirigida por Adorno à totalização de qualquer sistema teórico - crítica que consiste, não na desvalorização da negação, mas no acento em que a "negação da negação" não pode corresponder, sob pena de contribuir para a totalização do sistema, à mera afirmação do que foi anteriormente negado - trata-se de questionar se a actualização futura de uma possibilidade não seleccionada no passado coincide imediatamente com a "recuperação" do que foi excluído/preterido/ negado num primeiro momento.

Outra questão indissociável desta é a de saber se as noções de "potencial" e "virtual" coincidem. Em suma, trata-se de perguntar se há uma diferença qualitativa ou, ao invés, uma simples equivalência entre poder ser actualizado (associado ao "potencial" que antecede a actualização/afirmação) e não ter sido actualizado (associado ao "virtual" que procede da não-actualização/negação). À luz de um imperativo anti-totalizador, como o entendia, entre muitos outros, o autor de Negative Dialektik, esta diferença é fundamental, pois é decisivo insistir em que a negação altera qualitativamente o que nega.

(3) Apesar de célebre, a obra de Luhmann tem ocupado, pelo menos desde a transição para o século XXI, um lugar relativamente modesto no panorama internacional da reflexão sociológica e filosófica. Ainda assim, seria precipitado, se não erróneo, subestimar a disseminação dos seus contributos e, desde logo, restringir a nossa compreensão dessa disseminação à recepção explícita da sua obra. Vem isto a propósito da referência a uma proximidade implícita, e quem sabe se inconsciente, com a qual gostaria de terminar este breve comentário.

Em Warum es die Welt nicht gibt (2013) - bem como noutros trabalhos mais sistemáticos, como Transcendental Ontology (2011) - Markus Gabriel propõe-se repensar o debate ontológico contemporâneo, em termos que não deixam de ser social e psicologicamente significativos, tomando como ponto de partida uma reapropriação crítica da teoria dos mundos de Badiou. Fá-lo, estrategicamente, distanciando-se dos protagonistas do chamado "realismo especulativo" (Quentin Meillassoux, Ray Brassier, Iain Hamilton Grant, and Graham Harman).

Muito resumidamente, segundo Gabriel, a adopção do postulado da existência independente - que tão caro é ao realismo especulativo -, não nos obriga a enveredar por uma matematização da ontologia (como em Badiou ou, na sua esteira, em Meillassoux). Ao invés, defende Gabriel que é filosoficamente necessário investigar “as condições ontológicas [não só do que existe enquanto fenómeno, mas ainda] das nossas condições de acesso ao que existe [enquanto fenómeno]", e que tal implica postular que o sentido atravessa o plano do existente como um todo, embora para 
pensá-lo seja necessário reconhecer a multiplicidade coexistente, mas não totalizável, de “domínios de sentido". É para viabilizar este reconhecimento que Gabriel recorre e procura superar a "teoria dos mundos" de Badiou e parece acolher certas intuições caras à "teoria dos sistemas" de Luhmann.

Três aspectos do projecto teórico de Gabriel permitem arriscar este paralelo com Luhmann: a) o primado do sentido sobre o ser (subjacente à ideia de que não existe $o$ mundo, mas uma pluralidade de "domínios de sentido" que fazem mundos); b) a recusa em reduzir o sentido à sua determinação linguística e, por fim, c) a fidelidade a uma abordagem a um só tempo sistemática e não-totalizadora (traduzida na teorização de uma multiplicidade de "domínios de sentido" / "sistemas"). O que nos conduz a uma derradeira questão: seria a paixão pelo sistema aliada à paixão pela abertura do sistema o ipsissimum de Luhmann? E seria tal aliança - ou a promessa de tal aliança - a marca d'água dos seus seguidores apócrifos?

\section{BIBLIOGRAFIA}

Austin, J. L. “Truth”, in: Philosophical Papers. Oxford: Clarendon Press, 1961, 85-101 .

Ayer, A. J. "Negation", in: The Journal of Philosophy, Vol. 49, No 26 (Dec. 18, 1952), 797-815.

Baecker, Dirk. Wozu Systeme? Berlin: Kadmos Verlag, 2002.

Baecker, Dirk. "Niklas Luhmann in der Gesellschaft der Computer", in: Wozu Soziologie? Berlin: Kulturverlag Kadmos, 2004, 125-149.

Barel, Yves. Le paradoxe et le système: essai sur le fantastique social. Grenoble: Presses Universitaires de Grenoble, 1979.

Deleuze, Gilles. Logique du sens. Paris: Les Éditions de Minuit, 1969.

Frege, Gottlob. "Negation", in: Translations from the philosophical writings of Gottlob Frege. Edited by Peter Geach and Max Black, Transl. by P. Geach. Oxford: Basil Backwell, Second Edition, 1960, 117-135.

Freud, Sigmund. "Die Verneinung", in: Zeitschrift für Anwendung der Psychoanalyse auf die Geisteswissenschaften, XI. Band, Heft 3, 1925, 217-221.

Fuchs, Peter. Die Erreichbarkeit der Gesellschaft. Frankfurt am Main: Suhrkamp Verlag, 1992.

Fuchs, Peter. Die Metapher des Systems: Studien zu der allgemein leitenden Frage, wie sich der Tänzer vom Tanz unterscheiden lasse. Weilerswist: Velbrück Wissenschaft, 2001.

Fuchs, Peter. Der Eigen-Sinn des Bewußtseins. Die Person, die Psyche, die Signatur. Bielefeld: Transcript Verlag, 2003.

Fuchs, Peter. Der Sinn der Beobachtung. Begriffliche Untersuchungen. Weilerswist: Velbrück Wissenschaft, 2004. 
Fuchs, Peter. "Die Theorie der Systemtheorie - erkenntnistheoretisch", in: Idem, Theorie als Lehrgedicht. Systemtheoretische Essays I. Hrsg. von Marie-Christin Fuchs. Bielefeld: Transcript Verlag, 2004, 181-193.

Gabriel, Markus. Transcendental Ontology: Essays on German Idealism, New York/ London, Continuum, 2011.

Gabriel, Markus. Warum es die Welt nicht gibt, Berlin, Ullstein Verlag, 2013.

Günther, Gotthard. "Metaphysik, Logik und die Theorie der Reflexion", in: Beiträge zur Grundlegung einer operationsfähigen Dialektik, Erster Band. Hamburg: Felix Meiner Verlag, 1976, 31-74.

Habermas, J./Luhmann, N. Theorie der Gesellschaft oder Sozialtechnologie - Was leistet die Systemforschung? Frankfurt am Main: Suhrkamp Verlag, 10. Aufl., 1990.

Hahn, Alois. "Sinn und Sinnlosigkeit", in: Sinn, Kommunikation und soziale Differenzierung. Beiträge zu Luhmanns Theorie sozialer Systeme, Hrsg. von Hans Haferkamp und Michael Schmid. Frankfurt am Main: Suhrkamp Verlag, 1987, 155-164.

Hartley, Ralph. "Transmission of information", in: Bell System Technical Journal, Volume 7, Number 3 (July 1928), 535-563.

Heinemann, F. H. "The meaning of negation", in: Proceedings of the Aristotelian Society, New Series, Vol. 44 (1943-1944), 127-152.

Husserl, Edmund. Erfahrung und Urteil: Untersuchungen zur Genealogie der Logik, Ausg. und Hrsg. von Ludwig Landgrebe. Prag: Academia Verlagsbuchhandlung, 1939.

Luhmann, Niklas. Gesellschaftsstruktur und Semantik. Studien zur Wissenssoziologie der modernen Gesellschaft, Band I. Frankfurt am Main: Suhrkamp Verlag, 1980.

Luhmann, Niklas. Soziale Systeme. Grundriß einer allgemeinen Theorie. Frankfurt am Main: Suhrkamp Verlag, 1984.

Luhmann, Niklas. "Moderne Systemtheorien als Form gesamtgesellschaftlicher Analyse", in: Habermas, J./Luhmann, N., Theorie der Gesellschaft oder Sozialtechnologie. 1990, 7-24.

Luhmann, Niklas. "Sinn als Grundbegriff der Soziologie", in: Habermas, J./Luhmann, N., Theorie der Gesellschaft oder Sozialtechnologie. 1990, 25-100.

Luhmann, Niklas. Das Recht der Gesellschaft. Frankfurt am Main: Suhrkamp Verlag, 1993.

Luhmann, Niklas. Die Wissenschaft der Gesellschaf. Frankfurt am Main: Suhrkamp Verlag, 2. Aufl., 1994.

Luhmann, Niklas. Die Kunst der Gesellschaft. Frankfurt am Main: Suhrkamp Verlag, 1995.

Luhmann, Niklas. Die Gesellschaft der Gesellschaft. Band I. Frankfurt am Main: Suhrkamp Verlag, 1997.

Luhmann, Niklas. "The Paradox of Form”, in: Problems of Form. Edited by Dirk Baecker, Transl. by Michael Irmscher with Leah Edwards. Stanford: Stanford University Press, 1999, 15-26. 
Luhmann, Niklas. Die Religion der Gesellschaft. Frankfurt am Main: Suhrkamp Verlag, 2000.

Luhmann, Niklas. Soziologische Aufklärung 2: Aufsätze zur Theorie der Gesellschaft. Wiesbaden: VS Verlag für Sozialwissenschaften, 5. Aufl., 2005.

Luhmann, Niklas. Soziologische Aufklärung 3: Soziales System, Gesellschaft, Organisation. Wiesbaden: VS Verlag für Sozialwissenschaften, 4. Aufl., 2005.

Luhmann, Niklas. Aufsätze und Reden. Stuttgart: Reclam, 2007.

Luhmann, Niklas. Ideenevolution. Beiträge zur Wissenssoziologie. Hrsg. von André Kieserling. Frankfurt am Main: Suhrkamp Verlag, 2008.

Luhmann, Niklas. Schriften zu Kunst und Literatur. Hrsg. von Niels Werber. Frankfurt am Main: Suhrkamp Verlag, 2008.

Luhmann, Niklas. Die Realität der Massenmedien. Wiesbaden: VS Verlag für Sozialwissenschaften, 4. Aufl., 2009.

Luhmann, Niklas. Einführung in die Systemtheorie. Hrsg. von Dirk Baecker. Heidelberg: Carl-Auer Verlag, 6. Aufl., 2011.

MacKay, Donald. Information, Mechanism and Meaning. Cambridge, Massachusetts: The M.I.T. Press, $2^{\text {nd }}$ Edition, 1972.

Shannon, Claude/Weaver, Warren. The mathematical theory of communication. Urbana and Chicago: University of Illinois Press, 1998.

Spencer-Brown, George. Laws of Form. Leipzig: Bohmeier Verlag, $5^{\text {th }}$ Edition, 2011.

Whitehead, Alfred North. Process and Reality. Corrected Edition, Edited by David Ray Griffin and Donald W. Sherburne. New York: Simon and Schuster, 2010. 
(Página deixada propositadamente em branco.) 